\title{
Molecular characterization of a Trichinella spiralis elastase- 1 and its potential as a diagnostic antigen for trichinellosis
}

\author{
Chen Xi Hu, Peng Jiang, Xin Yue, Jie Zeng, Xin Zhuo Zhang, Yan Yan Song, Ruo Dan Liu, Xi Zhang, \\ Zhong Quan Wang* and Jing Cui
}

\begin{abstract}
Background: Trichinella spiralis muscle larval (ML) excretion/secretion (ES) antigen is the most widely used diagnostic antigen of trichinellosis, but preparation of ES antigen requires collecting worms from infected animals, and detection of specific lgG against MLES antigen may result in a false negative at the early stage of infection. The aim of the study was to characterize T. spiralis elastase-1 (TsEla) and to evaluate its potential as diagnostic antigen for trichinellosis.

Methods: The complete cDNA sequences of the TsEla gene were cloned and expressed, and recombinant (rTsEla) was purified. TsEla transcription and expression in different T. spiralis life-cycle stages was investigated by qPCR and western blotting, and its location in the nematodes was evaluated using an immunofluorescence assay (IFA). The antigenicity of rTsEla was investigated by western blotting analysis and ELISA. Anti-Trichinella lgG, IgM and IgE of experimentally infected mice and specific lgG antibodies of trichinellosis patients were assayed by rTsEla-ELISA and ES-ELISA.

Results: The results of the QPCR and western blotting showed that TsEla was expressed in various T. spiralis life stages. Natural TsEla was detected in the soluble proteins and ES proteins of different life stages. IFA revealed that TsEla was identified in the whole nematodes of various stages, especially in the cuticle, stichosome and genital primordium of the parasite. Serum anti-Trichinella lgM, lgG and IgE in infected mice was first detected by rTsEla-ELISA at 6, 10 and 12 days post-infection (dpi), and reached $100 \%$ at 8,14 and 14 dpi, respectively. When rTsEla-ELISA and ES-ELISA were used to detect anti-Trichinella lgG in sera of trichinellosis patients, the sensitivity was $97.37 \%$ (37/38) and $89.74 \%$ (34/38) $(P>0.05)$, and the specificity was $99.10 \%$ (220/222) and 98.20\% (218/222), respectively $(P>0.05)$. The rTsEla cross-reacted with only one serum sample out of 20 samples from paragonimiasis patients and 7 samples from clonorchiasis patients.
\end{abstract}

Conclusions: rTsEla is valuable to early diagnosis of trichinellosis and could be an alternative diagnostic antigen to the ML ES antigens.

Keywords: Trichinella spiralis, Trichinellosis, Elastase-1, Serodiagnosis

\section{Background}

Trichinellosis is a globally distributed food-borne parasitic disease. Humans can become infected by ingesting raw or semi-cooked meat containing Trichinella muscle

*Correspondence: wangzq2015@126.com; cuij@zzu.edu.cn Department of Parasitology, Medical College, Zhengzhou University, Zhengzhou 450052, China larvae (ML) [1]. Human Trichinella infection has been reported in 55 countries worldwide and trichinellosis is regarded to be a neglected zoonotic parasitosis. During 1986-2009, 65,818 cases and 42 deaths caused by trichinellosis were recorded in 41 countries [2, 3]. The main etiological agent of this disease is the common species T. spiralis. From 2004-2009, 15 trichinellosis outbreaks

(c) The Author(s) 2020. This article is licensed under a Creative Commons Attribution 4.0 International License, which permits use, sharing, adaptation, distribution and reproduction in any medium or format, as long as you give appropriate credit to the original author(s) and the source, provide a link to the Creative Commons licence, and indicate if changes were made. The images or other third party material in this article are included in the article's Creative Commons licence, unless indicated otherwise in a credit line to the material. If material is not included in the article's Creative Commons licence and your intended use is not permitted by statutory regulation or exceeds the permitted use, you will need to obtain permission directly from the copyright holder. To view a copy of this licence, visit http://creativeco mmons.org/licenses/by/4.0/. The Creative Commons Public Domain Dedication waiver (http://creativecommons.org/publicdomain/ zero/1.0/) applies to the data made available in this article, unless otherwise stated in a credit line to the data. 
were documented in the Chinese mainland which consisted of 1387 cases and 4 deaths, with the dominating infection source being pork [4-6]. Trichinellosis has become an important food-borne zoonosis with direct risk for food safety and public health $[7,8]$.

After the infected animal meat is eaten, infectious $T$. spiralis muscle larvae are released from their capsules under the digestion of gastric fluid, they develop in the intestine into infectious larvae, which intrude intestinal epithelium and, after 4 molts, mature into the adult stage (AW) $[9,10]$. The main symptom of the intestinal phase of trichinellosis is a non-specific gastroenteritis, with abdominal pain, diarrhea, nausea and/or vomiting, which may last up to 1 week. In 2-3 weeks after infection, each fertilized female deposits about 1500 newborn larvae (NBL), which migrate, penetrate and encapsulate in the host's skeletal muscle (acute or muscle stage) [11]. The acute stage results in an inflammatory reaction in response to the larval penetration of the muscles, and its obvious manifestations are fever, eyelid/facial oedema, myalgia, and eosinophilia [12, 13].

Because of the non-specific manifestations, clinical diagnosis of trichinellosis is difficult [12]. Muscle biopsy or detection of specific IgG against Trichinella is the most commonly used definitive diagnostic method for human Trichinella infection, but examination of muscle biopsies for detection of the parasite is insufficiently sensitive to find Trichinella larvae in the early and mild stages of infection [14]. The International Commission on Trichinellosis (ICT) recommended an ELISA with ML excretion/secretion (ES) antigen to detect anti-Trichinella IgG [15], but the primary weakness of an muscle larval (ML) $E S$ antigen is the potential of false-negatives due to specific IgG in the early stage of $T$. spiralis infection, which usually occurs in a 2-3 week window, because the major ML antigenic epitopes are stage-specific and can therefore only be probed by a ML stage-specific antibody [16]. The intestinal infective larvae (IIL) ES proteins are first exposed to the host's enteral local mucosal and systematic immune system which triggers the generation of Trichinella-specific antibodies $[17,18]$. The IIL ES proteins may contain early sero-diagnostic markers for $T$. spiralis infection [19]. Hence, the novel diagnostic antigens need to be exploited from the IIL ES proteins.

By immunoproteomics, several serine proteases have been identified in T. spiralis IIL and ML ES or surface proteins recognized using early infection serum [20-24]. Furthermore, T. spiralis serine proteases were highly expressed in IIL surface proteins relative to that of ML [25]. In this study, a novel T. spiralis elatase-1 gene (TsEla, GenBank: EFV56917.1) belonging to the serine protease family was obtained from the $T$. spiralis draft genome [26], cloned and expressed. Characteristics of the
TsEla were investigated and the prospective serodiagnostic value of recombinant TsEla (rTsEla) for trichinellosis was evaluated using serum samples from infected animals and patients.

\section{Methods}

Parasites and experimental animals

Trichinella spiralis strain (ISS534), which was used in this study, was obtained from a domestic pig in central China [27]. An additional 4 species of Trichinella were gifted by the International Trichinella Reference Centre (ITRC, Rome, Italy): T. nativa (T2, ISS10); T. britovi (T3, ISS100); T. nelsoni (T7, ISS29); and T. pseudospiralis (T4, ISS13) [28]. Their passage was carried out in six-weekold female BALB/c mice which obtained from the Henan Provincial Experimental Animal Center (Zhengzhou, China).

\section{Worm collection and protein preparation}

At 42 days post-infection (dpi), T. spiralis-infected mouse muscles were digested using $0.33 \%$ pepsin and $1 \% \mathrm{HCl}$ to recover the ML $[29,30]$. The IIL were collected from infected mouse intestine at $6 \mathrm{~h}$ post-infection (hpi) [25]. AW were acquired from duodenum and jejunum at 3 and $6 \mathrm{dpi}$, respectively [31]. Adult females were cultivated in RPMI-1640 medium containing 10\% fetal bovine serum (FBS; Gibco, Thermo Fisher Scientific, Waltham, MA, USA) at $37{ }^{\circ} \mathrm{C}$ for $24 \mathrm{~h}$, and then NBL were recovered [32]. The somatic crude or ES protein of NBL, ML, IIL and AW were prepared as previously described [33, 34].

\section{Serum samples}

Fifteen mice were infected orally with $200 \mathrm{~T}$. spiralis infective larvae. Following infection, $100 \mu \mathrm{l}$ of tail blood was obtained on alternate days during 2-60 dpi $[16,35]$. Serum samples collected at $35 \mathrm{dpi}$ were prepared from mice infected with 300 larvae of five Trichinella species (T. spiralis, T1; T. nativa, T2; T. britovi, T3; T. pseudospiralis, T4 and T. nelsoni, T7). Sera from mice infected with Toxoplasma gondii, Spirometra erinaceieuropaei plerocercoids, Schistosoma japonicum, Angiostrongylus cantonensis and Capillaria hepatica were provided by parasitologists from various Chinese universities. Serum samples of uninfected mice were used as a negative control.

Thirty-eight trichinellosis serum samples were collected from 2 trichinellosis outbreaks that occurred in western China during 2003-2013 [36]. The serum of patients with hepatic capillariasis $(n=5)$, ancylostomiasis $(n=1)$, clonorchiasis $(n=7)$, paragonimiasis $(n=20)$, schistosomiasis $(n=30)$, sparganosis $(n=8)$, cysticercosis $(n=20)$ and echinococcosis $(n=20)$ were stored within our department. The definite diagnosis of these patients 
was made according to stool parasite examination or serological tests [37, 38]. Serum samples of 111 healthy individuals who were from non-endemic areas of trichinellosis and tested negative for the above-mentioned parasitoses, were also assayed in this work.

\section{Bioinformatics analysis of TsEla}

The complete TsEla cDNA sequences were retrieved from GenBank (EFV56917.1). The characteristics of the TsEla gene were analyzed using bioanalysis software [39]. The tertiary structure and functional site of TsEla protein was predicted using PyMOL and CN3D software [40]. TsEla amino acid sequences were compared with elastases from other organisms by means of Clustal X [41]. The GenBank accession number of elastases from other organisms were as follows: Trichinella nativa KRZ58997.1; T. britovi KRY59723.1; T. pseudospiralis KRY01512.1; Trichinella sp. T6 KRX59470.1; Trichinella sp. T8 KRZ87740.1; Trichinella sp. T9 KRX64624.1; T. murrelli KRX35703.1; T. nelsoni KRX26142.1; T. patagoniensis KRY18991.1; T. zimbabwensis KRZ02345.1; Ancylostoma duodenale KIH49929.1; Necator americanus XP_013293254.1; Ascaris suum AEH42099.1; Wuchereria bancrofti EJW82097.1; Brugia malayi XP_001895362.1; Caenorhabditis elegans NP_494910.2; Mus musculus NP_291090.2; and Homo sapiens NP_001962.3. The maximum parsimony method was used to construct a phylogenetic tree of the elastase sequences using MEGA7.0 [42].

\section{Cloning and expression of rTsEla protein}

Total RNA from T. spiralis ML was extracted using Trizol (Invitrogen, Carlsbad, CA, USA), and reversely transcribed to the first strand cDNA. The TsEla gene was amplified by PCR with specific primers carrying $\mathrm{BamHI}$ and PstI restriction sites (underlined) (5'-CGG GAT CCT ATG AAT GTG GCA CCC TAC CAT CCA C-3', 5'-GCG CTG CAG TTA ACG GAA AAA GGT GAA TGT TGG ATC ATT-3'). The PCR product was cloned into expression vector $\mathrm{pQE}-80 \mathrm{~L}$. The recombinant $\mathrm{pQE}$ 80L/TsEla was transformed into Escherichia coli BL21. Expression of rTsEla was induced at $37^{\circ} \mathrm{C}$ for $6 \mathrm{~h}$ using $1.0 \mathrm{mM}$ IPTG. rTsEla protein was purified using a NiNTA-Sefinose resin (Sangon Biotech, Shanghai, China) [43]. rTsEla proteins were analyzed on SDS-PAGE as previously described $[44,45]$.

\section{Preparation of polyclonal antibodies against rTsEla}

Fifteen mice were immunized subcutaneously with $20 \mu \mathrm{g}$ rTsEla mixed 1:1 (v/v) with complete Freund's adjuvant. Three booster immunizations were administered using the same dose of rTsEla mixed with incomplete Freund's adjuvant at a two-week interval [46]. Two weeks after the final boost, $100 \mu \mathrm{l}$ of tail blood was taken from immunized mice, and anti-rTsEla serum was isolated [47].

\section{Western blotting analysis}

Somatic soluble proteins of $T$. spiralis different life stages and rTsEla were separated on SDS-PAGE, and transferred onto nitrocellulose membranes (Merck Millipore, Billerica, MA, USA) at $18 \mathrm{~V}$ for $35 \mathrm{~min}$ [48]. The membrane was cut into strips, and blocked using $5 \%$ skimmed milk at $37^{\circ} \mathrm{C}$ for $2 \mathrm{~h}$. After washing with TBS-0.5\% Tween 20 (TBST), the strips were probed with anti-rTsEla serum (1:100) for $2 \mathrm{~h}$ at $37^{\circ} \mathrm{C}$, followed by incubation with HRPanti-mouse IgG conjugate (1:5000; Southern Biotech, Tuscaloosa, AL, USA) at $37^{\circ} \mathrm{C}$ for $1 \mathrm{~h}$. Following washing again, the strips were developed using 3,3'-diaminobenzidine tetrahydrochloride (DAB; Sigma-Aldrich, St. Louis, MO, USA) [31, 49].

qPCR

Total RNA of different $T$. spiralis life stages (NBL, ML, IIL, $3 \mathrm{~d}$ AW and $6 \mathrm{~d}$ AW) was extracted using Trizol reagent (Invitrogen). TsEla transcription levels were detected by qPCR with specific primers (5'-TGG AAA AAG ATG GTA ATA GAA TA A A-3'; $5^{\prime}$-TGT TAT CAA AAT CTG CAT AGT AGG T-3') as previously reported $[50,51]$. T. spiralis internal control gene GAPDH (GenBank: AF452239) was amplified as a positive control [52]. PBS served as a negative control. TsEla transcription level was standardized by deducting the GAPDH transcription level and then calculated by comparative $\mathrm{Cq}\left(2^{-\Delta \Delta \mathrm{Cq}}\right)$ [53].

\section{Immunofluorescence assay (IFA)}

To locate TsEla in worm tissues, IFA was performed with $T$. spiralis whole worms and their cross-sections $[54,55]$. The integrated parasite was fixed in cold acetone for $20 \mathrm{~min}$ and $2 \mu \mathrm{m}$ worm cross-sections were cut using a microtome. The whole worms and cross-sections were blocked with $1 \%$ bovine serum albumin (BSA) and probed by anti-rTsEla serum diluted at $1: 10$ at $37^{\circ} \mathrm{C}$ for $2 \mathrm{~h}$. After washing with PBS, they were incubated at $37^{\circ} \mathrm{C}$ for $1 \mathrm{~h}$ with cy3/FITC anti-mouse IgG conjugate (1:100; Santa Cruz Biotech, Dallas, Texas, USA), and examined using fluorescence microscopy (Olympus, Tokyo, Japan) [56].

\section{Application of rTsEla-ELISA to assay Trichinella-specific antibodies}

Anti-Trichinella IgG, IgM and IgE of experimentally infected mice and specific IgG antibodies of trichinellosis patients were assayed by ELISA with rTsEla (rTsElaELISA) and ML ES antigens (ES-ELISA) $[57,58]$. Optimal 
dilutions of antigens and sera were first determined using a checkerboard titration. The optimal antigen coating concentration was $2.0 \mu \mathrm{g} / \mathrm{ml}$ rTsEla for detecting specific IgG and IgM, $3.5 \mu \mathrm{g} / \mathrm{ml}$ rTsEla for detecting IgE, and $2.5 \mu \mathrm{g} / \mathrm{ml}$ ES antigens for IgG, IgM and IgE. Microtiter plates were coated with the above mentioned antigens, and blocked using $5 \%$ skimmed milk at $37{ }^{\circ} \mathrm{C}$ for $2 \mathrm{~h}$. After washes with PBST, the plates were probed with mouse sera (1:100 for IgG and 1:50 for IgM and IgE), and human sera diluted at 1:200 for detecting three antibodies, subsequently incubated at $37{ }^{\circ} \mathrm{C}$ for $1 \mathrm{~h}$ with HRPlabelled anti-human/mouse IgG antibody (1:10,000; Southern Biotech). Following washes, the plates were developed using o-phenylenediamine dihydrochloride (OPD; Sigma-Aldrich) with $30 \% \mathrm{H}_{2} \mathrm{O}_{2}$ for $30 \mathrm{~min}$, and the reaction was stopped using $2 \mathrm{M} \mathrm{H}_{2} \mathrm{SO}_{4}$. The absorbance (optical density, OD) at $492 \mathrm{~nm}$ was assayed with a microplate reader (TECAN, Schweiz, AG, Switzerland), and all serum samples were tested in duplicate. The ratio $<2.1$ of tested serum/negative serum OD values was considered as negative and the ratio $\geq 2.1$ as positive [ 59 , 60]. For detecting mouse serum IgG, IgM and IgE, the cut-off values for rTsEla-ELISA were $0.25,0.24$ and 0.21 , respectively; and those for ES-ELISA were 0.29, 0.27 and 0.23 , respectively. The cut-off values of rTsEla-ELISA and ES-ELISA for detecting human IgG were 0.34 and 0.61 , respectively.

\section{Statistical analysis}

SPSS 21.0 software was used to statistically analyze the data. Data are shown as the arithmetic mean \pm standard deviation (SD). TsEla transcription and expression in different $T$. spiralis life stages were compared using one-way ANOVA. The difference between groups was determined by Chi-square test. A statistical difference was considered significant at $P<0.05$.

\section{Results}

\section{Bioinformatics analysis of TsEla}

Complete TsEla coding sequence consisted of $1350 \mathrm{bp}$ encoding 449 amino acids (aa), with a molecular weight $(\mathrm{MW})$ of $47.3 \mathrm{kDa}$ and isoelectric point (pI) of 8.88 . A signal peptide at 19 aa was detected by Signal P 4.1 Server. TMHMM prediction revealed that TsEla has no transmembrane domain, but has a functional domain named as Tryp_SPc located at $38-314$ aa. The TsEla homology comparison of the TsEla gene with those of other species or genotypes of Trichinella is shown in Fig. 1. The TsEla amino acid sequence had an identity of 87.2, 81.6, 78.1, 77.9, 77.6, 75.4 and 72.0\% with elastase of the 7 species with encapsulated larvae (T. nelsoni, $T$. nativa, T. britovi, T9, T6, T. murrelli and T8), and an identity of 70.6 and $67.3 \%$ with species with non-encapsulated larvae (T. pseudospiralis and T. zimbabwensis, respectively).

Phylogenetic analysis of TsEla with elastase- 1 from other nematodes is shown in Fig. 2a. The phylogenetic tree shows the monophyletic group of above-mentioned 10 Trichinella species/gene types, except for the recently described T. patagoniensis from Argentina. According to the phylogenetic analysis of elastase, T. spiralis has a closer evolutionary relationship with the species of the genus with encapsulated larvae. The structure prediction revealed that TsEla has $5 \alpha$-helices and $37 \beta$-strands, a catalytic site Ile, and three serine protease-specific active sites (His, Asp and Ser) (Fig. 2b, c).

\section{SDS-PAGE and western blotting analysis of rTsEla}

SDS-PAGE revealed that BL21 bacteria incorporating PQE-80L/TsEla, expressed a 47.3 kDa fusion protein. After purification, the rTsEla protein exhibited a clear individual band (Figs. 3, 4d). The MW (47.3 kDa) of the rTsEla protein was identical with its predicted MW size (47.3 kDa).

To assess the murine humoral response to rTsEla, anti-rTsEla IgG antibody in immunized mice was measured by ELISA. The results indicated anti-rTsEla IgG was induced by immunization with rTsEla. The specific IgG titer was up to $1: 10^{5}$ after the fourth immunization, demonstrating that the rTsEla has good immunogenicity. Western blotting revealed that three bands of native TsEla with $40.9-59.8 \mathrm{kDa}$ in soluble protein of different $T$. spiralis life stages (NBL, ML, IIL, 3d and 6d AW) were detected by anti-rTsEla serum (Fig. 4b), 2-9 bands of native TsEla with $27.8-62.6 \mathrm{kDa}$ in $\mathrm{ML}$, IIL and $3 \mathrm{~d}$ AW ES proteins was also probed using antirTsEla serum (Fig. 4c). Eight bands of native TsEla with 25.9-52.8 $\mathrm{kDa}$ in ML soluble proteins, three bands of native TsEla with $44.3-52.8 \mathrm{kDa}$ in ML ES proteins, and rTsEla were detected by anti-rTsEla serum, but not by non-infected serum (Fig. 4d), indicating that TsEla was expressed at diverse $T$. spiralis stages, and it is a secretory protein of this nematode.

\section{qPCR analysis of TsEla gene transcription in different life stages of $T$. spiralis}

Transcription of the TsEla gene in different life stages of $T$. spiralis was detected by qPCR, the results revealed that the TsEla gene was transcribed at all T. spiralis stages (NBL, ML, IIL, $3 \mathrm{~d}$ and $6 \mathrm{~d}$ AW) (Fig. 5). The transcription level in the ML stage was obviously higher than those of the other stages $\left(F_{(4,10)}=287.184, P<0.001\right)$, and the TsEla level in the IIL stage was higher than those in the NBL and AW stage $(P<0.0001)$, but lower than that in the ML stage $(P<0.0001)$. 


\begin{tabular}{|c|c|c|}
\hline T. spiralis & 1 & C) \\
\hline T. nelsoni & 1 & 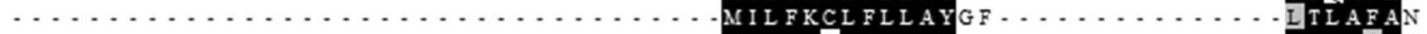 \\
\hline T. nativa & & \\
\hline T. britovi & & \\
\hline T. sp. T9 & & \\
\hline & 1 & $\mathrm{KCLYLLAL}$ \\
\hline & & $\ldots \ldots \ldots$ MHSLLVDVPYFS \\
\hline T. sp. T8 & 1 & MLIEFHCCVTPGRVDVGQKDIMKDLPKIPTRDNVKDTP \\
\hline & & \\
\hline T. $z$ & & $\ldots \ldots \ldots \ldots \ldots \ldots \ldots$ \\
\hline T. spiralis & 39 & . . GGSVATPNS I PYQARLVLEKDGNRIKLCGGTLVELKPGNGSQWVL TAAHC \\
\hline & 41 & ... GGSVATPNS I P YQARLFLEKDGNKVKLCGGTLVELKPGNGSQWVL TAAHC \\
\hline & 39 & GGSVATPNS I PYQARLVLEKDGNKIKLCGGTLVELKPGNGSQWVLTAAHC \\
\hline & 25 & S I P YQARL VLEKDGNRI IL CGGSL VELKPGNGSQWVL T AAHC \\
\hline & 39 & GGSVATPNS I P YQARL MLEKDGNKVKLCGGTLVELKPGNGSQWVL TAAHC \\
\hline & 39 & GGSVAIP NSLP YQAR I VMEKNGNK I KL C GGTLVEL KP GNGS QWVI TAAHC \\
\hline & & GGSVATPNSI P YQARLVFKKAGDRVKLCGGSLVELKPGNGSQWVL T AAHC \\
\hline & & DSVSRSRSDVRFGFNDPSFTFFRGSAIPNSLPYQARL VMEKAGDKLKLCGGTLVELKPGNGSQWVLTAAHC \\
\hline T. pseudospiralis & & A........................... \\
\hline & & s. . . . . . . . . \\
\hline T. $s p$ & 117 & KVE V I L GAHR P NEKEST QH TV \\
\hline & & \\
\hline & 101 & I R S ACL P KVNEPVPL DVP \\
\hline T. $b_{1}$ & & 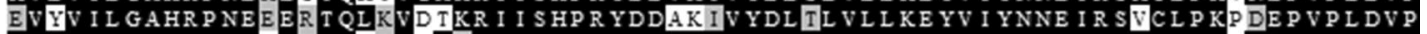 \\
\hline & & RYDDVATVYDL SLVLLKEYVIYNNE IR SACLPKVNEPVPLDVP \\
\hline & 103 & E I R S ACL P KVNE P V P L DV P \\
\hline & & KVDTKR I I SHPR YDDVELVYDLTLVLLKEYVIYI \\
\hline & & AAIVYDLSLVLLKEYVIY \\
\hline & 103 & KVEV I L GAHRPNEDEKT QV KVGAKR I I SHPRYDDNL \\
\hline asis & & KVTV I L GAHR PSEKEKT QVRVGAKR I I SHPR YDDD \\
\hline & & PEEHAIV FCAFGVDR SATCQGDSGG \\
\hline & 203 & VIFCAYGVDRSATC \\
\hline & & CAYGVDRSATC \\
\hline & 171 & VFCAYGVDRSATCQGDS \\
\hline T. sp & 203 & EHA I V FCAYGVDR SATCQGDSG \\
\hline & & \\
\hline & 205 & RPE E HA I I FCAYGVAR S A TCQGDS \\
\hline T. sp. & 269 & KPEEHAI IFCAYGVDR SATC \\
\hline & 185 & TLYGITSFGP \\
\hline & & \\
\hline & 317 & -VTPGSVDVGQKDIMKI \\
\hline & 303 & \\
\hline & 301 & NYKGSDVFNF \\
\hline & 269 & VT P GR VDAGKKD I MKK DL PQI I I \\
\hline & 303 & VT P GRVEVGQKDIEKDLPK I P \\
\hline & & VT P GRVDVGQKDIMKDL PK I \\
\hline & & V T P GR V DV GQKD I MKDL P K I \\
\hline & 367 & SYKGSDVFN \\
\hline & 283 & VDDRQKD ITKDFNNI PS \\
\hline T. zimbal & & FNNIDSRDNVKDT-NGYKGSDVEDS \\
\hline & 40 & \\
\hline & & \\
\hline & & GGINGGRELNS-PRVFIETKTINHRPSLSRSRSDV-ESVSTDKQYRNAWPSRTILN \\
\hline & 368 & GGNKGGSIENS-PRVFIETKTVNRLPSVSRSESDVGRFGFN . . DDPTETFFR \\
\hline & & - PRVFIETKTINHRPSISRSRSDVAESVSTDKQYRNAWPSRTILN \\
\hline & 359 & $76.9 \%$ \\
\hline T. murre & 388 & PSVSRILADIPYFPFTLKE . . IETN \\
\hline & 466 & PSVSR SR SDVGRFGFN. \\
\hline & 377 & GGNTGGSFFSSSPGV FRETRTTNKL P SV SR SR SDVGR F GFN \\
\hline & & GNNGGSFRSSSPRVRRETRTVNRLPSVSRSKSDVGRFGF \\
\hline
\end{tabular}

Fig. 1 Sequence alignment of Trichinella spiralis elastase gene (XP_003377838.1) with other Trichinella species or genotypes. Clustal X and BOXSHADE were used to analyze the sequences, obvious differences were observed in different species/genotypes. Black shading represents the residues identical to TsEla, and grey shading shows the conservative substitutions

Expression and localization of TsEla in different $T$. spiralis stages by IFA

IFA was used to detect the expression and localization of TsEla in T. spiralis stages. IFA with entire worms detected positive fluorescence staining in the epicuticle of ML, early IIL (3, 6 and 12 h IIL) and NBL by antirTsEla serum, but no immunostaining was found in late IIL (15 and $24 \mathrm{~h} \mathrm{IIL)} \mathrm{and} 3 \mathrm{~d}$ AW (Fig. 6), suggesting that native TsEla was expressed in the epicuticle of ML, early IIL and NBL, but not in the epicuticle of late IIL and AW stages. When worm cross-sections were used in IFA, fluorescence staining was distributed within the whole body in ML, $6 \mathrm{~h}$ IIL and $3 \mathrm{~d}$ AW, especially in the cuticle, stichosome and genital primordium of the parasites (Fig. 7). No fluorescence staining in ML was observed by incubation with mouse pre-infected serum. 

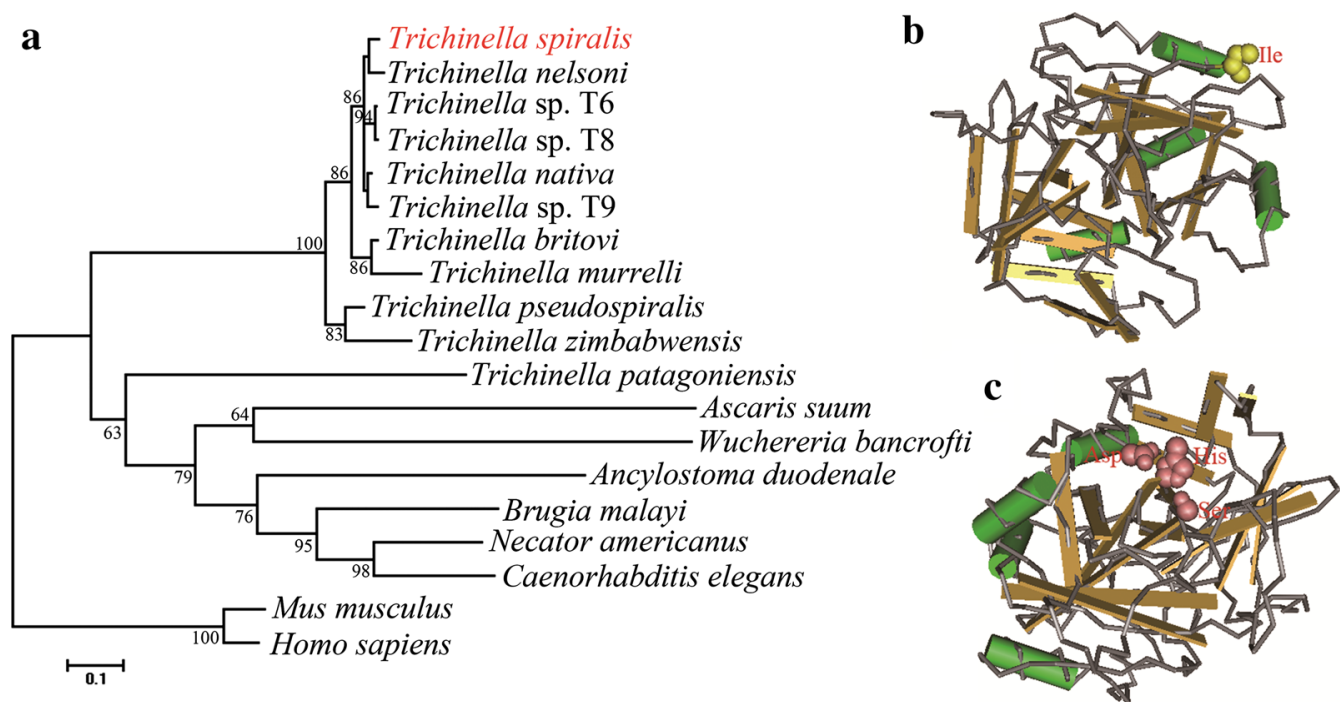

Fig. 2 Phylogenetic tree of elastases of 19 organisms generated with MP method (a) and the predicted 3-dimensional structure of TsEla protein (b, c). $\mathbf{b}$ The predicted catalytic site lle of the TsEla (in yellow). c Three serine protease-specific active sites (His, Asp and Ser) of TsEla, which are marked as red

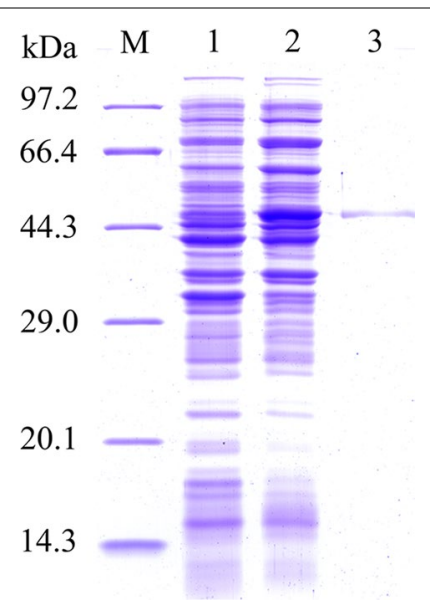

Fig. 3 SDS-PAGE analysis of rTsEla. Lane M: protein marker; Lane 1: lysate of BL21 bacteria containing pQE-80L/TsEla before induction; Lane 2: lysate of BL21 bacteria containing pQE-80L/TsEla following induction; Lane 3: rTsEla after purification

\section{Assay of Trichinella-specific lgG in sera of mice infected with Trichinella and other parasites}

Trichinella-specific IgG in serum samples from mice infected with T. spiralis and other parasites was tested using rTsEla-ELISA and ES-ELISA; the result is shown in Table 1. The detection rate of specific IgG using two antigens was $100 \%$ of mice infected with 300 T. spiralis ML at $35 \mathrm{dpi}$. Both antigens did not cross-react with sera from mice infected with T. gondii, Capillaria hepatica, A. cantonensis, Clonorchis sinensis and S. japonicum. However, ML ES antigen had a cross-reactivity with one serum
(4.8\%) from sparganum-infected mice. Specific IgG in serum from mice infected with 300 larvae of other Trichinella species were also measured using two antigens (Table 2). The IgG detection rate with two antigens had also no significant difference in mice infected with the other four Trichinella species $\left(\chi_{(1)}^{2}=0.317, P=0.573\right)$.

\section{Dynamics of serum Trichinella-specific lgG, IgM and IgE in mice infected with 200 larvae}

At $10 \mathrm{dpi}$, anti-Trichinella IgG was primarily detected in $73.33 \%(11 / 15)$ of infected mice by rTsEla-ELISA and in $20 \%(3 / 15)$ by ES-ELISA $\left(\chi_{(1)}^{2}=8.571, P=0.003\right)$. Seroconversion reached $100 \%(15 / 15)$ at 14 and 18 dpi determined by two antigens, respectively (Fig. 8a, b), and remained as this until the end of the experiment (60 dpi). When anti-Trichinella IgM was assayed, it was first detected at $6 \mathrm{dpi}$ in $40 \%(6 / 15)$ of infected mice by rTsEla-ELISA and in $20 \%(3 / 15)$ by ES-ELISA $\left(\chi_{(1)}^{2}=1.429, P=0.232\right)$, and the seroconversion reached the peak $(100 \%)$ at $8 \mathrm{dpi}$, persisted to $24 \mathrm{dpi}$, but was not detected by $28 \mathrm{dpi}$ (Fig. 8c, d). When anti-Trichinella IgE was measured by two antigens, it was first detected at 12 dpi in $20 \%$ and in $26.7 \%$ of infected mice $\left(\chi^{2}{ }_{(1)}=0.186\right.$, $P=0.666)$, respectively; antibody positivity reached $100 \%$ at $14 \mathrm{dpi}$, and became negative by 28 and $26 \mathrm{dpi}$, respectively (Fig. 8e, f).

\section{Assay of Trichinella-specific IgG in serum of trichinellosis patients}

Sensitivity of rTsEla-ELISA and ES-ELISA for assaying Trichinella-specific IgG in serum from trichinellosis 

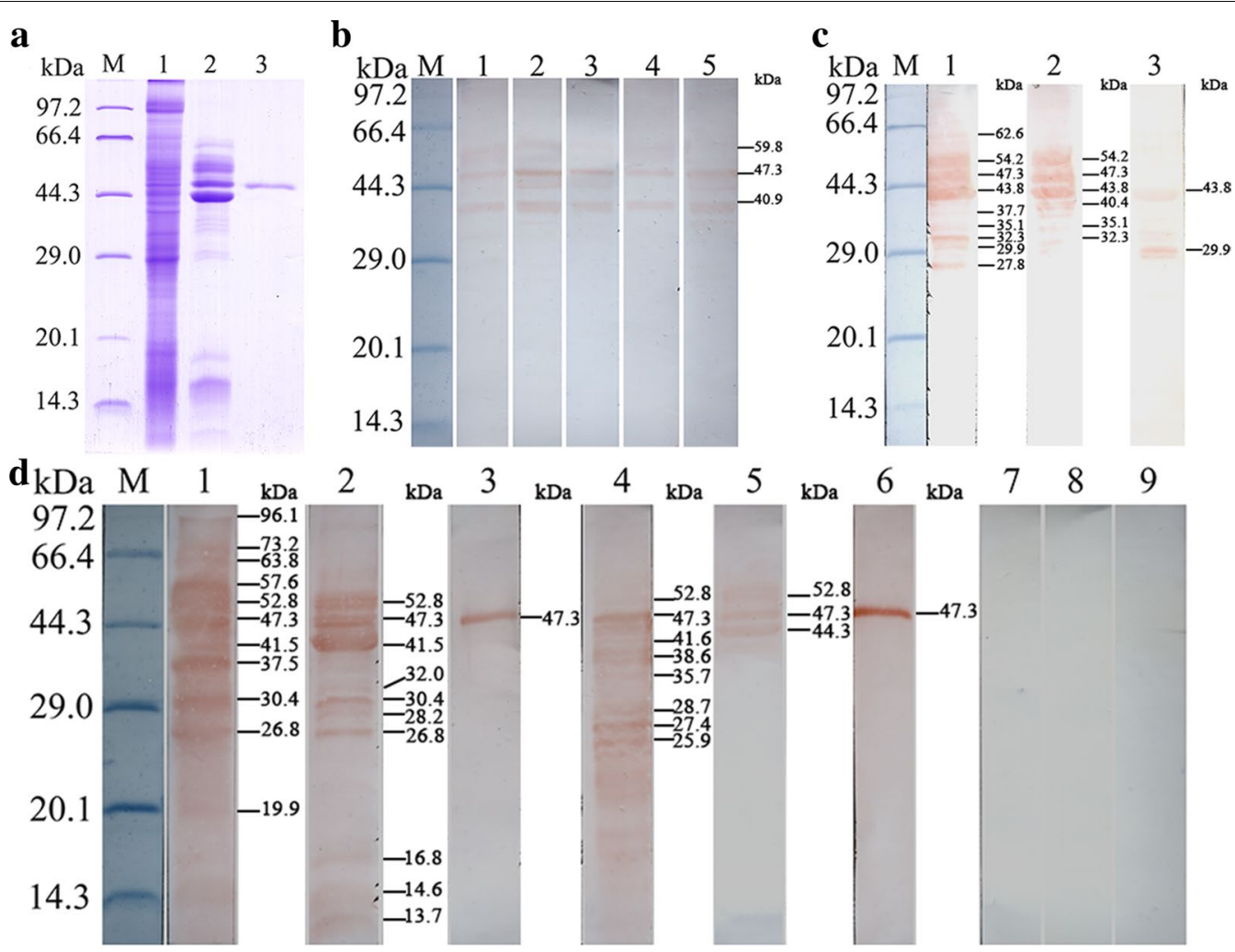

Fig. 4 Western blotting identification of rTsEla. a SDS-PAGE analysis of rTsEla. Lane M: protein marker; Lane 1: ML soluble proteins; Lane 2: ML ES proteins; Lane 3: purified rTsEla. b Western blotting revealed natural TsEla in soluble proteins of T. spiralis NBL (Lane 1), ML (Lane 2), IIL (Lane 3), 3d AW (Lane 4) and 6d AW (Lane 5) were probed by anti-rTsEla serum. c Western blotting showed that native TsEla in ES proteins of ML (Lane 1), IIL (Lane 2) and $3 \mathrm{~d}$ AW (Lane 3) were detected by anti-rTsEla serum. d Western blotting of rTsEla antigenicity. ML soluble protein (Lane 1), ML ES protein (Lane 2) and rTsEla (Lane3) were probed by T. spiralis-infected mouse sera as positive serum control; native TsEla in ML soluble (Lane 4) and ES protein (Lane 5), and rTsEla (Lane 6) were recognized by anti-rTsEla serum; ML soluble (Lane 7) and ES protein (Lane 8), and rTsEla (Lane 9) were not probed by uninfected mouse serum as negative serum control

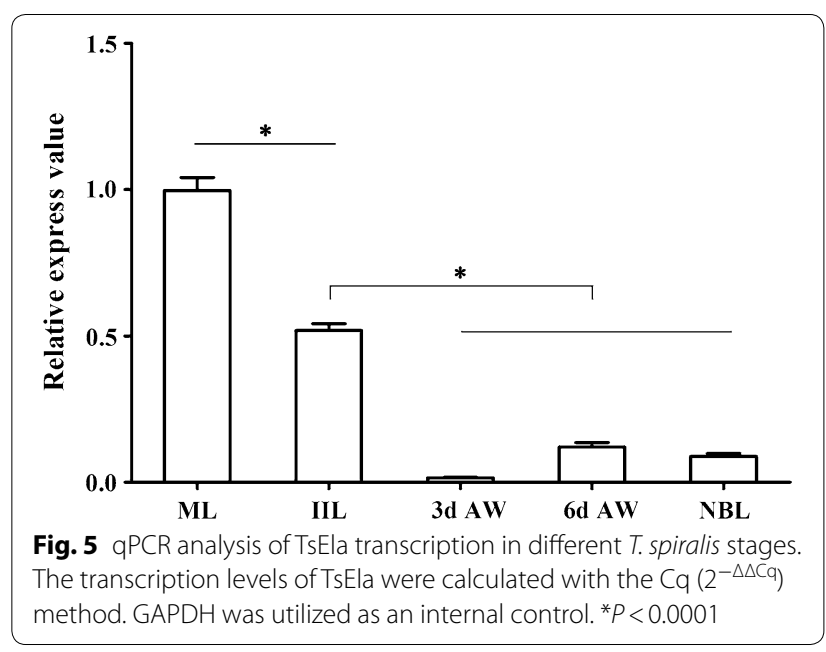

patients was $97.37 \%(37 / 38)$ and $89.74 \%(34 / 38)$, respectively $\left(\chi_{(1)}^{2}=1.020, P=0.312\right)$. When the patients sera were tested at $19 \mathrm{dpi}$, the sensitivity of rTsEla was $92.31 \%$ (12/13), which had no statistical difference compared with $76.92 \%(10 / 13)$ for the ES antigen $\left(\chi_{(1)}^{2}=1.927\right.$, $P=0.165$ ) (Table 3). The specificity of rTsEla and ES antigen was $99.10 \%(220 / 222)$ and $98.20 \%(218 / 222)$ $\left(\chi_{(1)}^{2}=0.676, P=0.411\right)$, when they were used to assay anti-Trichinella IgG in patients with other parasitoses and healthy individuals. No cross-reaction of rTsEla was observed with serum samples of patients with hepatic capillariasis, ancylostomiasis, schistosomiasis, cysticercosis, sparganosis, and echinococcosis, but rTsEla did cross-react with one serum from a patient with paragonimiasis and another with clonorchiasis (Fig. 9). 


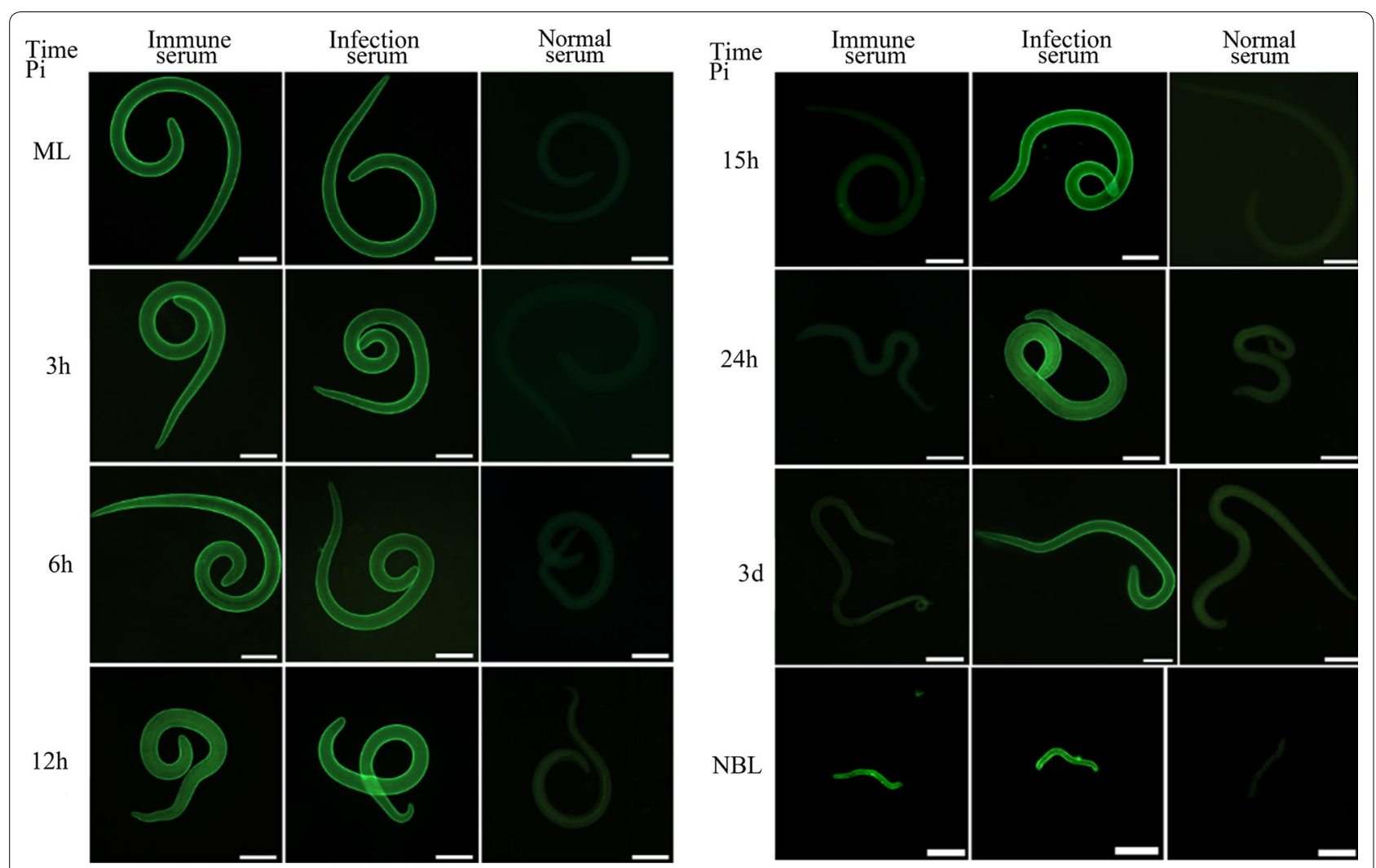

Fig. 6 Expression of TsEla at the surface of different T. spiralis stages by IFA with anti-rTsEla serum. Fluorescence staining was found at the cuticle of ML, 3-12 h IIL and NBL by using anti-rTsEla serum, but no immunostaining was found in the cuticle of 15-24 h IIL and $3 \mathrm{~d}$ AW. The worms reacted with infected or uninfected serum as a positive or negative control. Scale-bars: $100 \mu \mathrm{m}$

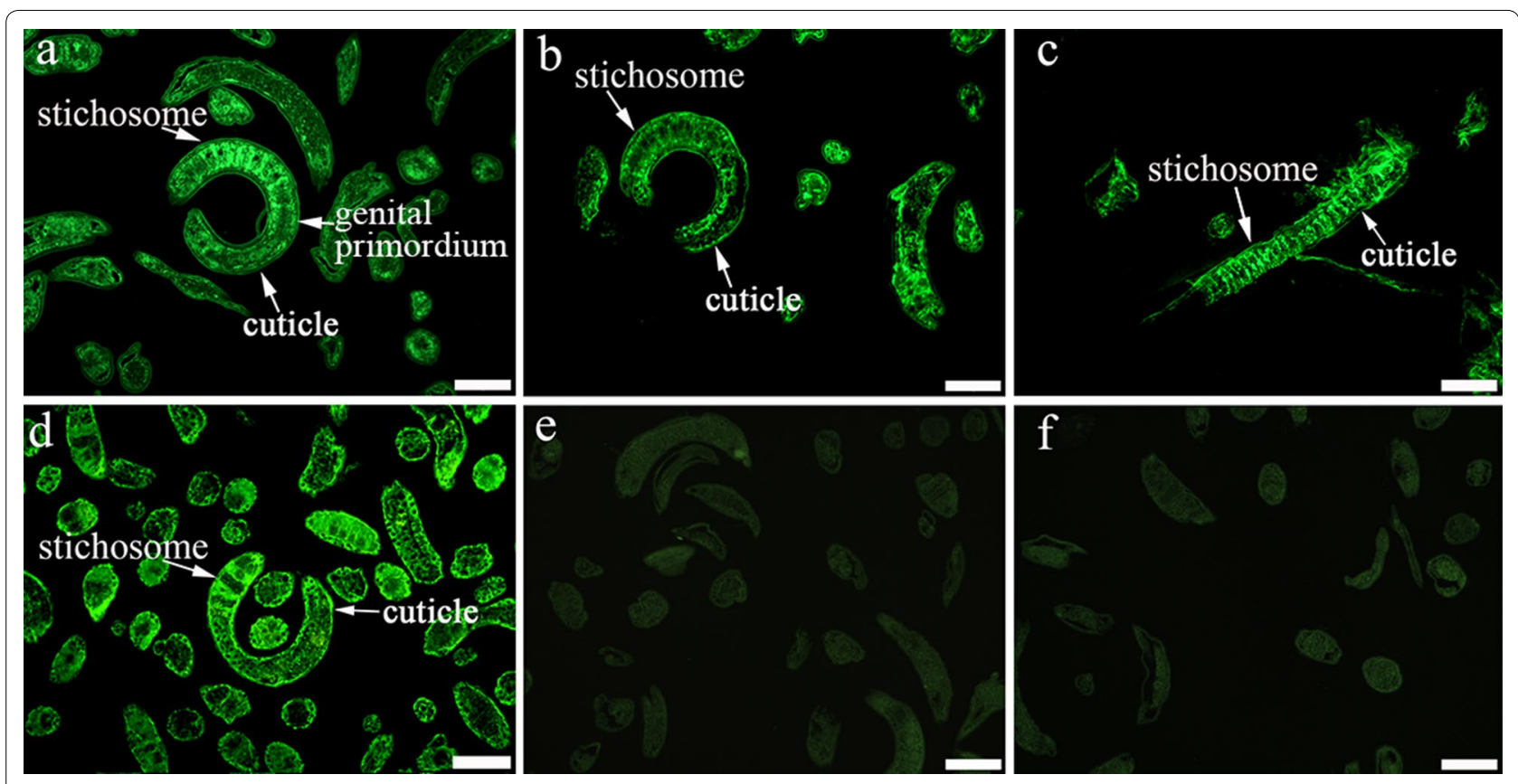

Fig. 7 Immunolocalization of TsEla in cross-sections of different T. spiralis life stages by IFA with anti-rTsEla serum. The parasite cross-sections were probed using anti-rTsEla serum, and fluorescence staining was seen in the cuticle and stichosome of ML (a), $6 \mathrm{~h} \mathrm{IIL} \mathrm{(b)} \mathrm{and} 3 \mathrm{~d} \mathrm{AW}$ (c). ML cross-sections were incubated with infection sera (d) as a positive control, uninfected sera (e) and PBS (f) as negative controls. Scale-bars: $100 \mu \mathrm{m}$ 
Table 1 Detection of serum anti-Trichinella lgG in mice infected with Trichinella spiralis and other parasites by rTsE-ELISA and ES-ELISA

\begin{tabular}{|c|c|c|c|c|c|}
\hline \multirow[t]{2}{*}{ Parasite species } & \multirow[t]{2}{*}{ No. of serum samples } & \multicolumn{2}{|c|}{ ELISA with rTsE } & \multicolumn{2}{|c|}{ ELISA with ML ES } \\
\hline & & $\mathrm{OD} \pm \mathrm{SD}$ & $\begin{array}{l}\text { No. of positive samples } \\
\text { (\%) }\end{array}$ & $\mathrm{OD} \pm \mathrm{SD}$ & $\begin{array}{l}\text { No. of } \\
\text { positive } \\
\text { samples (\%) }\end{array}$ \\
\hline Trichinella spiralis & 20 & $1.24 \pm 0.72$ & $20(100)$ & $1.32 \pm 0.77$ & $20(100)$ \\
\hline Capillaria hepatica & 10 & $0.05 \pm 0.03$ & $0(0)$ & $0.06 \pm 0.03$ & $0(0)$ \\
\hline Angiostrongylus cantonensis & 12 & $0.05 \pm 0.02$ & $0(0)$ & $0.05 \pm 0.01$ & $0(0)$ \\
\hline Clonorchis sinensis & 20 & $0.11 \pm 0.05$ & $0(0)$ & $0.13 \pm 0.06$ & $0(0)$ \\
\hline Schistosoma japonicum & 16 & $0.09 \pm 0.05$ & $0(0)$ & $0.11 \pm 0.06$ & $0(0)$ \\
\hline Spirometra erinacei & 21 & $0.12 \pm 0.01$ & $0(0)$ & $0.16 \pm 0.06$ & $1(4.8)$ \\
\hline Toxoplasma gondii & 6 & $0.07 \pm 0.05$ & $0(0)$ & $0.08 \pm 0.05$ & $0(0)$ \\
\hline
\end{tabular}

Abbreviations: OD, OD-value; SD, standard deviation

Table 2 Detection of serum anti-Trichinella lgG in mice infected with four Trichinella species by ELISA provide the same detail as in Table 1

\begin{tabular}{|c|c|c|c|c|c|}
\hline \multirow[t]{2}{*}{ Parasite species } & \multirow[t]{2}{*}{ No. of serum samples } & \multicolumn{2}{|c|}{ ELISA with rTsE } & \multicolumn{2}{|c|}{ ELISA with ML ES } \\
\hline & & $\mathrm{OD} \pm \mathrm{SD}$ & No. of positive samples (\%) & $\mathrm{OD} \pm \mathrm{SD}$ & $\begin{array}{l}\text { No. of } \\
\text { positive } \\
\text { samples (\%) }\end{array}$ \\
\hline T. nativa & 23 & $0.48 \pm 0.31$ & $21(91.3)$ & $0.51 \pm 0.34$ & $21(91.3)$ \\
\hline T. britovi & 14 & $0.71 \pm 0.36$ & $14(100)$ & $0.68 \pm 0.38$ & $14(100)$ \\
\hline T.pseudospiralis & 30 & $0.39 \pm 0.23$ & $22(73.3)$ & $0.4 \pm 0.24$ & $20(66.7)$ \\
\hline T. nelsoni & 15 & $0.75 \pm 0.47$ & 14 (93.3) & $0.72 \pm 0.47$ & 14 (93.3) \\
\hline
\end{tabular}

Abbreviations: OD, OD-value; SD, standard deviation

\section{Discussion}

Detection of circulating antigen or DNA from live Trichinella worms is an ideal early diagnostic technique for detecting Trichinella infection. However, the content of Trichinella circulating antigen and DNA in serum samples is usually low and difficult to detect $[16,61]$. In addition, the easy degrading and short duration of Trichinella DNA leads to its non-application as a diagnostic marker for Trichinella infection [62, 63]. Hence, novel diagnostic antigens for early Trichinella infection need to be explored.

Elastases are the trypsin-like proteins belonging to the family of serine proteases, they can degrade host's various macromolecular substances such as keratin, laminin, type IV collagen, fibronectin and elastin [64]. The elastases are involved in larva invasion, molting and digestion, and may exert a major action for parasite invasion $[65,66]$. Elastases are likely significant target antigens for eliciting an immune response at an early stage of infection, and may be used as diagnostic markers for early parasitic diseases. Nevertheless, studies on elastases were mainly focused on Schistosoma spp. [67, 68]; we found no reports of studies on T. spiralis elastase in the literature.
In the present study, the complete TsEla sequence was cloned and expressed in E. coli. Bioinformatics analysis showed that the TsEla had a signal peptide and one functional domain of three serine protease-specific active sites. Sequence analysis showed that TsEla has $87.2 \%$ and $81.6 \%$ identity with the elastase of T. nelsoni and T. nativa, respectively. The phylogenetic tree indicated TsEla had a close evolutionary relationship with elastase of T. nelsoni, and demonstrated a monophyletic group of 10 Trichinella species/gene types, except for T. patagoniensis which was recently found in a cougar from Argentina [69]. Following purification, the rTsEla was highly immunogenic and used to produce anti-rTsEla serum. Immunization of mice with rTsEla triggered the obvious antibody responses to rTsEla. qPCR revealed that TsEla transcription was detected in various $T$. spiralis stages (ML, IIL, AW and NBL), indicating that TsEla was transcribed at every life-cycle stage of this nematode, and the TsEla transcription level at ML and IIL stages was remarkably greater than that of other stages as shown in Fig. 5. Western blotting showed that several native TsEla protein bands in ML somatic and ES proteins were identified by anti-rTsEla serum, it is likely because TsEla might have various isoforms, or this protein was 

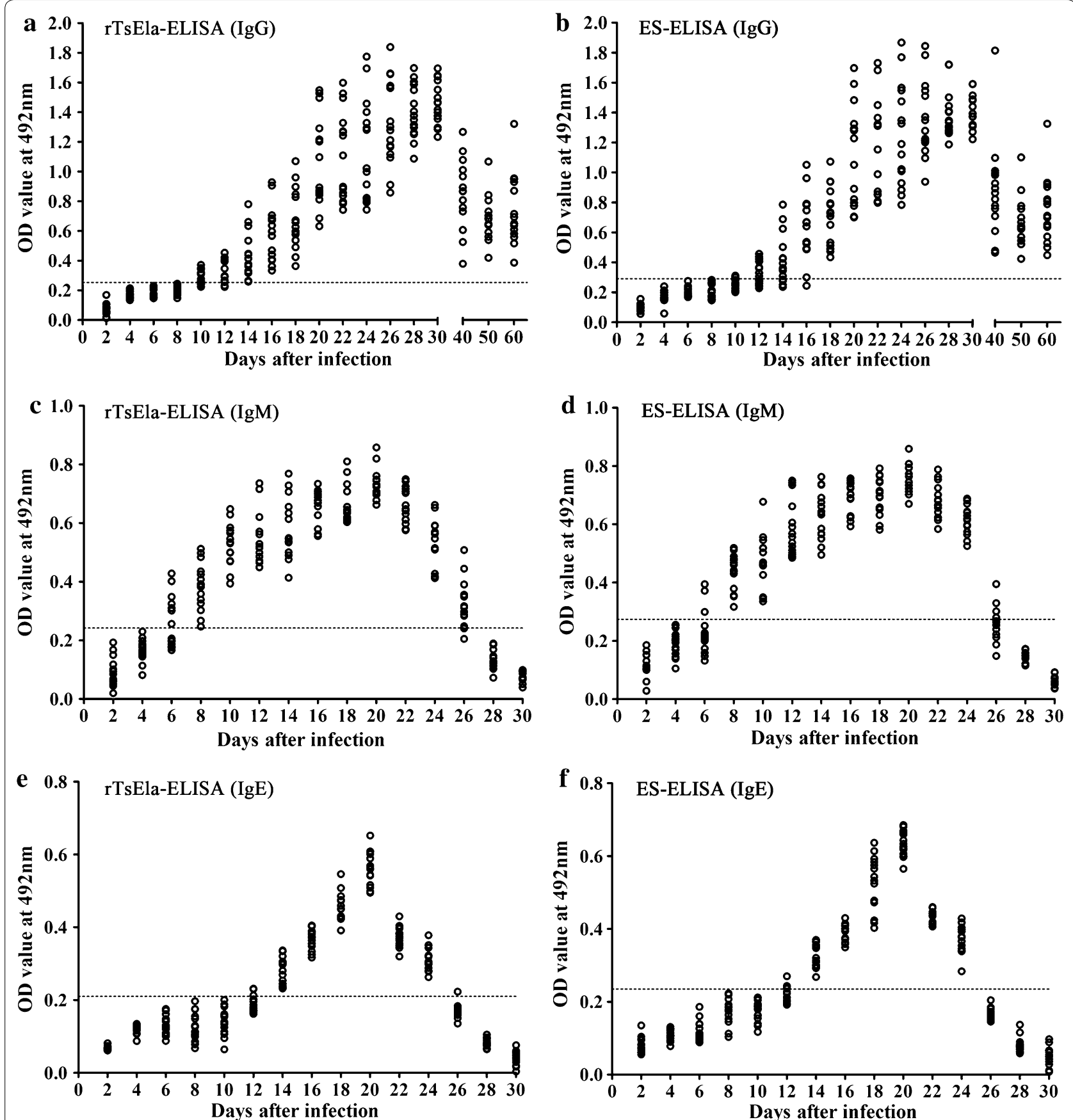

Fig. 8 Kinetics of serum Trichinella-specific antibodies in mice infected with 200 T. spiralis larvae. Specific lgG was measured with rTsEla-ELISA (a) and ES-ELISA (b); anti-Trichinella IgM by rTsEla-ELISA (c) and ES-ELISA (d), and anti-Trichinella lgE by rTsEla-ELISA (e) and ES-ELISA (f). The dotted lines represent the cut-off values

possibly processed by post-translational modifications and processing, or because TsEla is one member of the Trichinella serine protease superfamily and possesses the same antigenic epitopes [13, 36, 70].
Western blotting results also revealed that native TsEla in ML, IIL and $3 \mathrm{~d}$ AW ES proteins were recognized by anti-rTsEla serum. The results of IFA with intact worms showed that native TsEla was mainly expressed in the epicuticle of ML, early IIL (3-12 h IIL) and NBL, but not 
Table 3 Detection of anti-Trichinella lgG antibodies in serum samples of patients with trichinellosis and other parasitoses by rTsEELISA and ES-ELISA

\begin{tabular}{|c|c|c|c|c|c|}
\hline \multirow{2}{*}{$\begin{array}{l}\text { Sera of mice infected with } \\
\text { specific parasites }\end{array}$} & \multirow[t]{2}{*}{ No. of serum samples } & \multicolumn{2}{|c|}{ ELISA with rTsE } & \multicolumn{2}{|c|}{ ELISA with ML ES } \\
\hline & & $\mathrm{OD} \pm \mathrm{SD}$ & $\begin{array}{l}\text { No. of positive samples } \\
(\%)\end{array}$ & $\mathrm{OD} \pm \mathrm{SD}$ & $\begin{array}{l}\text { No. of } \\
\text { positive } \\
\text { samples (\%) }\end{array}$ \\
\hline Trichinellosis & 38 & $0.95 \pm 0.41$ & $37(97.37)$ & $1.00 \pm 0.44$ & $34(89.47)$ \\
\hline Early trichinellosis ${ }^{\mathrm{a}}$ & 13 & $0.97 \pm 0.54$ & $12(92.31)$ & $1.00 \pm 0.58$ & $10(76.92)$ \\
\hline Late trichinellosis ${ }^{\mathrm{b}}$ & 25 & $0.94 \pm 0.32$ & $25(100)$ & $1.00 \pm 0.34$ & $24(96.00)$ \\
\hline Hepatic capillariasis & 5 & $0.24 \pm 0.04$ & $0(0)$ & $0.21 \pm 0.03$ & $0(0)$ \\
\hline Ancylostomiasis & 1 & 0.167 & $0(0)$ & 0.152 & $0(0)$ \\
\hline Paragonimiasis & 20 & $0.27 \pm 0.14$ & $1(5.00)$ & $0.28 \pm 0.16$ & $2(10.00)$ \\
\hline Schistosomiasis & 30 & $0.21 \pm 0.06$ & $0(0)$ & $0.28 \pm 0.07$ & $0(0)$ \\
\hline Clonorchiasis & 7 & $0.34 \pm 0.13$ & $1(14.29)$ & $0.41 \pm 0.13$ & $2(28.57)$ \\
\hline Cysticercosis & 20 & $0.24 \pm 0.11$ & $0(0)$ & $0.27 \pm 0.11$ & $0(0)$ \\
\hline Echinococcosis & 20 & $0.18 \pm 0.10$ & $0(0)$ & $0.30 \pm 0.10$ & $0(0)$ \\
\hline Sparganosis & 8 & $0.20 \pm 0.06$ & $0(0)$ & $0.21 \pm 0.07$ & $0(0)$ \\
\hline Healthy individuals & 111 & $0.16 \pm 0.06$ & $0(0)$ & $0.29 \pm 0.04$ & $0(0)$ \\
\hline
\end{tabular}

${ }^{a}$ Early trichinellosis, the sera of patients with early trichinellosis was collected at 19 days after infection

b Late trichinellosis, the sera of patients with late trichinellosis was collected at 35 days after infection

Abbreviations: OD, OD-value; SD, standard deviation

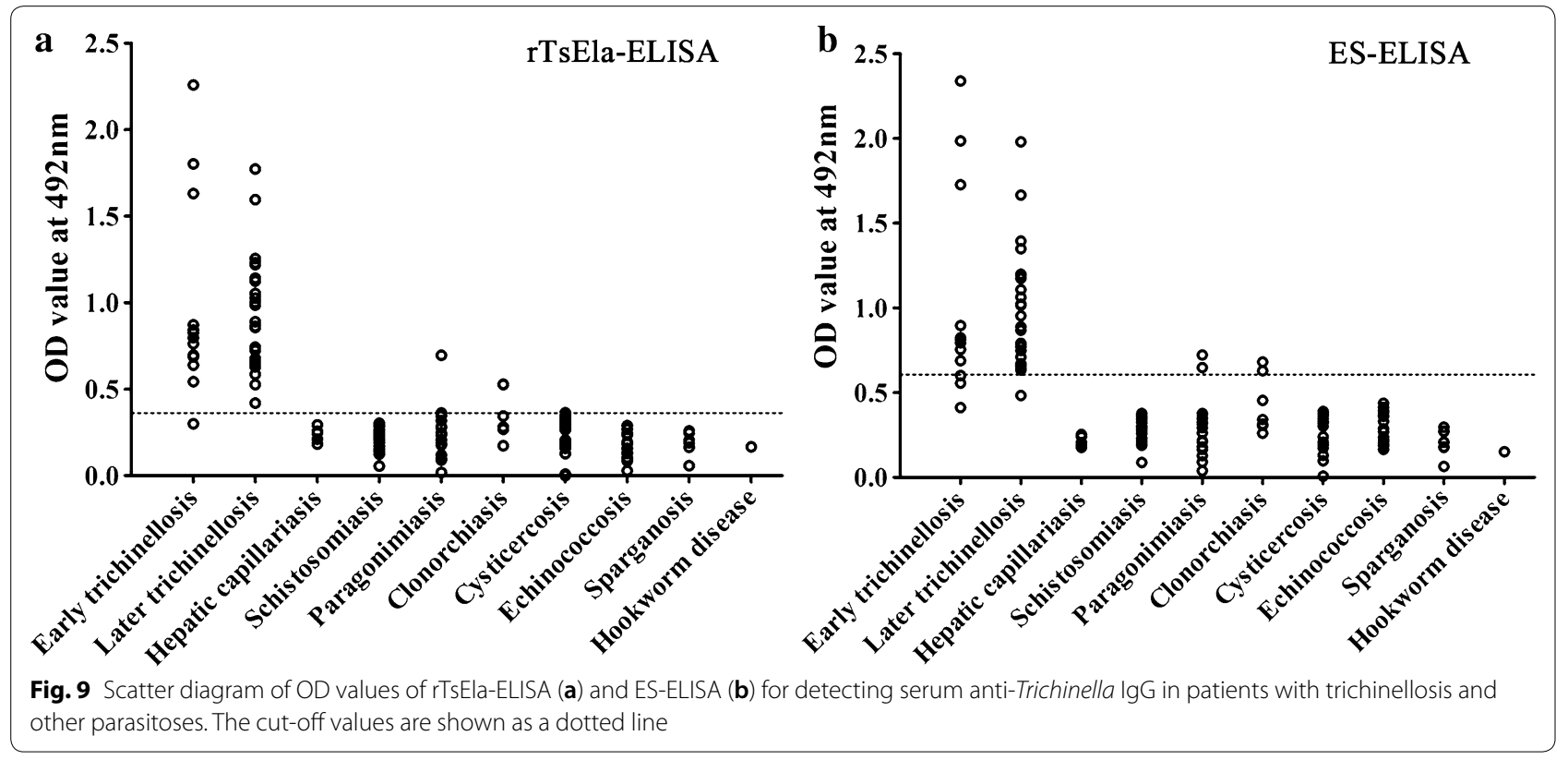

in late IIL (15-24 h IIL) and AW. The native TsEla was distributed in the whole worms of ML, $6 \mathrm{~h}$ IIL and $3 \mathrm{~d}$ AW, especially in the cuticle, stichosome and genital primordium of the parasite when worm cross-sections were used. Concerning the TsEla location, some differences in $3 \mathrm{~d}$ adults occurred between Figs. 6 and 7c, it is likely because when whole worms were used in the IFA, their surface cuticle was intact, and the inner antigens were not exposed, and not recognized by anti-rTsEla serum. Whereas when the cross-sections of $3 \mathrm{~d}$ adult worms were prepared, the worm surface cuticle (epicuticle) might be destroyed by the hot paraffin in the process of worm embedding, so the inner antigens were exposed and therefore recognized and immuno-stained. These results suggest that TsEla is a secretory protein which is likely derived from surface/ES protein of this nematode. 
Previous studies have demonstrated that other T. spiralis serine proteases (TspSP-1.2, TsSP and Ts31) were also expressed in the cuticle and ES products of the parasitic nematode $[13,36,48]$, suggesting that TsEla is an indispensable protein of parasite-host interaction, and might have an important action in larva invasion and eliciting an early immune response. However, the rTsEla enzyme activity and functions need to be further investigated.

In order to evaluate the rTsEla potential for serodiagnosis of trichinellosis, an rTsEla-ELISA was established, and the results were comparatively analyzed with those of a conventional ML ES-ELISA. Our results revealed that anti-Trichinella IgM, IgG and IgE in infected mice were first detected by rTsEla-ELISA at 6, 10, $12 \mathrm{dpi}$, and reached $100 \%$ at 8,14 and $14 \mathrm{dpi}$, respectively. When the ES-ELISA was used, anti-Trichinella IgM, IgG and IgE in infected mice were first detected at 6, 10, $12 \mathrm{dpi}$, and reached $100 \%$ at 8,18 and $14 \mathrm{dpi}$, respectively, indicating that anti-Trichinella IgM levels rapidly elevated during the early phase of Trichinella infection, but declined quickly from the beginning of $26 \mathrm{dpi}$ when the larvae were encapsulated in the skeletal muscles [11]. The results suggest that detection of anti-Trichinella IgM is valuable only for early trichinellosis [16, 71]. Because of the short half-life in serum samples, IgE had no advantage to conventional IgG detection [12, 72]. The amount and avidity of IgG antibodies was found to be most useful for serodiagnosis of trichinellosis [73], the seroconversion time following primary Trichinella infection was dependent on the infectious dose and muscle larva burden, anti-Trichinella IgG was usually detected approximately 2-3 weeks post-infection in infected animals, and may remain for many years [74].

Interestingly, Trichinella-specific IgG in 100\% of mice infected with $200 \mathrm{~T}$. spiralis larvae were detected using rTsEla-ELISA as early as $14 \mathrm{dpi}$, but the ES-ELISA could not detect all of the infected mice prior to $18 \mathrm{dpi}$. Our results suggest that TsEla as a surface/ES protein of ML and early IIL was exposed with host's immune system at an early stage of the infection, triggering an early specific IgG response which continued to the muscle stage $[17$, 25].

In order to ascertain the sensitivity and specificity of rTsEla for detecting anti-Trichinella IgG, rTsEla-ELISA was used to test serum samples from patients with trichinellosis and other parasitoses, and the results were compared with ES-ELISA. The results showed that the sensitivity of rTsEla-ELISA and ES-ELISA was $97.37 \%$ and $89.47 \%$, respectively $(P>0.05)$. When the serum samples from patients at the early stage of trichinellosis at $19 \mathrm{dpi}$ were examined, the sensitivity of rTsEl-ELISA (92.31\%) was higher than $76.92 \%$ of ES-ELISA, but there was no statistically significant difference $(P>0.05)$; this result is likely because only a few of the early serum samples were assayed. Specificity of rTsEla and ES antigens was $99.10 \%$ and $98.20 \%$, respectively $(P>0.05)$, when the two antigens were used to test Trichinella-specific IgG in sera from patients with other helminthiases and healthy individuals. rTsEla cross-reacted with only one out of 20 paragonimiasis patients and seven clonorchiasis patients. Because of the long-time storage and repeated freezing/ thawing of these serum samples, anti-Trichinella IgM in our patients' sera were not detected (data not shown). Sensitivity and specificity of rTsEla are comparative to those of recombinant Ts31 and TsSP proteins $[13,36]$. Moreover, preparation of ML ES antigens requires collecting the infectious larvae from experimentally infected animals, which is inconvenient due to labor, time and costs [32]. Recombinant antigens can be produced in vitro in large quantities and may be used as a diagnostic antigen in a standardized ELISA to diagnose trichinellosis [58]. Therefore, the rTsEla is worthy of early serodiagnosis of trichinellosis, and could be useful as a potential alternative diagnostic antigen to the ML ES antigens.

\section{Conclusions}

Our study indicates that TsEla was transcribed and expressed in all life-cycle stages of T. spiralis, it was likely derived from the nematode's surface and ES proteins, and located in the whole worm body. The rTsEla had a good immunogenicity. The sensitivity and specificity of rTsEla for assaying Trichinella-specific IgG and IgM are comparable to the commonly used muscle larval ES antigens. The rTsEla is a worthy candidate for early serodiagnosis of trichinellosis and could be a potential alternative antigen to the ML ES antigens. However, more serum samples from patients at an early stage of Trichinella infection are needed to further ascertain its sensitivity and specificity.

\section{Abbreviations}

AW: adult worms; BSA: bovine serum albumin; DAB: 3,3'-diaminobenzidine tetrahydrochloride; dpi: days post-infection; ES: excretion/secretion; FBS: fetal bovine serum; ICT: International Commission on Trichinellosis; IFA: immunofluorescence assay; IIL: intestinal infective larvae; ML: muscle larvae; MP: maximum parsimony; MW: molecular weight; NBL: newborn larvae; OD: optical density; OPD: o-phenylenediamine dihydrochloride; TBST: TBS- $0.5 \%$ Tween 20; TsEla: T. spiralis elastase-1.

\section{Acknowledgements}

The authors wish to thank Professor Guo Rong Yin (Shanxi Medical University), Professor Jia Hui Lei (Tongji Medical College, Huazhong University of Science and Technology), Professor Zi Yue Lv (Zhongshan School of Medicine, Sun Yat-Sen University), and Dr Lei Wang (Beijing Institute of Tropical Medicine), who provided the serum samples of mice infected with Toxoplasma gondii, Schistosoma japonicum, Angiostrongylus cantonensis and Capillaria hepatica, respectively. 


\section{Authors' contributions}

ZQW and JC designed this study. CXH, PJ, XY, JZ, YYS, RDL and XZ performed the experiments. $\mathrm{CXH}$ analyzed the data with assistance of $\mathrm{PJ}$ and $\mathrm{XZ}$. $\mathrm{CXH}$, ZQW and JC drafted and revised the manuscript. All authors read and approved the final manuscript.

\section{Funding}

This study was supported by grants of the National Natural Science Foundation of China (81601788, U1704284).

\section{Availability of data and materials}

The data supporting the conclusions of this article are included within the article.

\section{Ethics approval and consent to participate}

This study was conducted on the basis of National Guidelines for Experimental Animal Welfare (Minister of Science and Technology, the People's Republic of China, 2006). Laboratory animal application in the study were approved by the Zhengzhou University Life Sciences Ethics Committee (No. SCXK 2017-0001). All serum samples of patients and healthy persons were obtained from adult individuals, and written informed consent was obtained.

\section{Consent for publication}

Not applicable.

\section{Competing interests}

The authors declare that they have no competing interests.

Received: 18 December 2019 Accepted: 18 February 2020 Published online: 24 February 2020

\section{References}

1. Rostami A, Gamble HR, Dupouy-Camet J, Khazan H, Bruschi F. Meat sources of infection for outbreaks of human trichinellosis. Food Microbiol. 2017:64:65-71.

2. Pozio E. World distribution of Trichinella spp. infections in animals and humans. Vet Parasitol. 2007;149:3-21.

3. Murrell KD, Pozio E. Worldwide occurrence and impact of human trichinellosis, 1986-2009. Emerg Infect Dis. 2011;17:2194-202.

4. Cui J, Wang ZQ, Xu BL. The epidemiology of human trichinellosis in China during 2004-2009. Acta Trop. 2011;118:1-5.

5. Cui J, Jiang P, Liu LN, Wang ZQ. Survey of Trichinella infections in domestic pigs from northern and eastern Henan, China. Vet Parasitol. 2013;194:133-5.

6. Cui J, Wang ZQ. An epidemiological overview of swine trichinellosis in China. Vet J. 2011:190:323-8.

7. Jiang P, Zhang X, Wang LA, Han LH, Yang M, Duan JY, et al. Survey of Trichinella infection from domestic pigs in the historical endemic areas of Henan province, central China. Parasitol Res. 2016;115:4707-9.

8. Bai X, Hu X, Liu X, Tang B, Liu M. Current research of trichinellosis in China. Front Microbiol. 2017:8:1472

9. Ren HJ, Cui J, Wang ZQ, Liu RD. Normal mouse intestinal epithelial cells as a model for the in vitro invasion of Trichinella spiralis infective larvae. PLoS ONE. 2011;6:10.

10. Liu RD, Wang ZQ, Wang L, Long SR, Ren HJ, Cui J. Analysis of differentially expressed genes of Trichinella spiralis larvae activated by bile and cultured with intestinal epithelial cells using real-time PCR. Parasitol Res. 2013;112:4113-20.

11. Despommier DD. How does Trichinella spiralis make itself at home? Parasitol Today. 1998;14:318-23.

12. Dupouy-Camet J, Kociecka W, Bruschi F, Bolas-Fernandez F, Pozio E. Opinion on the diagnosis and treatment of human trichinellosis. Expert Opin Pharmacother. 2002;3:1117-30.

13. Sun GG, Song YY, Jiang P, Ren HN, Yan SW, Han Y, et al. Characterization of a Trichinella spiralis putative serine protease. Study of its potential as serodiagnostic tool. PLoS Negl Trop Dis. 2018;12:e0006485.

14. Wang ZQ, Shi YL, Liu RD, Jiang P, Guan YY, Chen YD, et al. New insights on serodiagnosis of trichinellosis during window period: early diagnostic antigens from Trichinella spiralis intestinal worms. Infect Dis Poverty. 2017;6:41.

15. Gamble HR, Pozio E, Bruschi F, Nockler K, Kapel CMO, Gajadhar AA. International commission on Trichinellosis: recommendations on the use of serological tests for the detection of Trichinella infection in animals and man. Parasite. 2004;11(1):3-13.

16. Liu LN, Jing FJ, Cui J, Fu GY, Wang ZQ. Detection of circulating antigen in serum of mice infected with Trichinella spiralis by an IgY-lgM mAb sandwich ELISA. Exp Parasitol. 2013:133:150-5.

17. Sun GG, Liu RD, Wang ZQ, Jiang P, Wang L, Liu XL, et al. New diagnostic antigens for early trichinellosis: the excretory-secretory antigens of Trichinella spiralis intestinal infective larvae. Parasitol Res. 2015:114:4637-44.

18. Sun GG, Wang ZQ, Liu CY, Jiang P, Liu RD, Wen H, et al. Early serodiagnosis of trichinellosis by ELISA using excretory-secretory antigens of Trichinella spiralis adult worms. Parasites Vectors. 2015;8:484

19. Xu DM, Wen H, Wang LA, Hu CX, Qi X, Sun GG, et al. Identification of early diagnostic antigens in soluble proteins of Trichinella spiralis adult worms by western blot. Trop Biomed. 2017;34:191-8.

20. Cui J, Liu RD, Wang L, Zhang X, Jiang P, Liu MY, et al. Proteomic analysis of surface proteins of Trichinella spiralis muscle larvae by two-dimensional gel electrophoresis and mass spectrometry. Parasites Vectors. 2013;6:355.

21. Liu RD, Cui J, Wang L, Long SR, Zhang X, Liu MY, et al. Identification of surface proteins of Trichinella spiralis muscle larvae using immunoproteomics. Trop Biomed. 2014;31:579-91.

22. Liu RD, Jiang P, Wen H, Duan JY, Wang LA, Li JF, et al. Screening and characterization of early diagnostic antigens in excretory-secretory proteins from Trichinella spiralis intestinal infective larvae by immunoproteomics. Parasitol Res. 2016;115:615-22.

23. Wang L, Wang ZQ, Cui J. Proteomic analysis of the changed proteins of Trichinella spiralis infective larvae after co-culture in vitro with intestinal epithelial cells. Vet Parasitol. 2013;194:160-3.

24. Wang L, Cui J, Hu DD, Liu RD, Wang ZQ. Identification of early diagnostic antigens from major excretory-secretory proteins of Trichinella spiralis muscle larvae using immunoproteomics. Parasites Vector. 2014;7:40.

25. Liu RD, Cui J, Liu XL, Jiang P, Sun GG, Zhang X, et al. Comparative proteomic analysis of surface proteins of Trichinella spiralis muscle larvae and intestinal infective larvae. Acta Trop. 2015;150:79-86.

26. Mitreva M, Jasmer DP, Zarlenga DS, Wang ZY, Abubucker S, Martin J, et al. The draft genome of the parasitic nematode Trichinella spiralis. Nat Genet. 2011;43:228-35.

27. Wang ZQ, Li LZ, Jiang P, Liu LN, Cui J. Molecular identification and phylogenetic analysis of Trichinella isolates from different provinces in mainland China. Parasitol Res. 2012:110:753-7.

28. Li LZ, Wang ZQ, Jiang P, Zhang X, Ren HJ, Cui J. Molecular identification of a Trichinella isolate from a naturally infected pig in Tibet, China. Korean J Parasitol. 2011:49:381-4.

29. Li F, Cui J, Wang ZQ, Jiang P. Sensitivity and optimization of artificial digestion in the inspection of meat for Trichinella spiralis. Foodborne Pathog Dis. 2010;7:879-85.

30. Jiang P, Wang ZQ, Cui J, Zhang X. Comparison of artificial digestion and Baermann's methods for detection of Trichinella spiralis pre-encapsulated larvae in muscles with low-level infections. Foodborne Pathog Dis. 2012:9:27-31.

31. Yang W, Li LG, Liu RD, Sun GG, Liu CY, Zhang SB, et al. Molecular identification and characterization of Trichinella spiralis proteasome subunit beta type-7. Parasites Vectors. 2015;8:18.

32. Wu Z, Nagano I, Takahashi Y, Maekawa Y. Practical methods for collecting Trichinella parasites and their excretory-secretory products. Parasitol Int 2016:65:591-5.

33. Wang L, Wang ZQ, Cui J. Protein changes in Trichinella spiralis muscle larvae in vitro induced by bovine bile. Vet Parasitol. 2013;194:164-7.

34. Wang ZQ, Liu RD, Sun GG, Song YY, Jiang P, Zhang X, et al. Proteomic analysis of Trichinella spiralis adult worm excretory-secretory proteins recognized by sera of early patients with trichinellosis. Front Microbiol. 2017;8:986.

35. Long $S R$, Tian XY, Wang ZQ, Liu RD, Liu LN, Jiang P, et al. Serodiagnosis of trichinellosis by ELISA using recombinant nudix hydrolase of Trichinella spiralis. Trop Biomed. 2015;32:669-75. 
36. Cui J, Wang L, Sun GG, Liu LN, Zhang SB, Liu RD, et al. Characterization of a Trichinella spiralis $31 \mathrm{kDa}$ protein and its potential application for the serodiagnosis of trichinellosis. Acta Trop. 2015;142:57-63.

37. Cui J, Li N, Wang ZQ, Jiang P, Lin XM. Serodiagnosis of experimental sparganum infections of mice and human sparganosis by ELISA using ES antigens of Spirometra mansoni spargana. Parasitol Res. 2011;108:1551-6.

38. Wang ZQ, Cui J, Wang Y. Persistent febrile hepatomegaly with eosinophilia due to hepatic capillariasis in China. Ann Trop Med Parasitol. 2011:105:469-72.

39. Zhang YL, Zhang HW, Zhang X, Liu LN, Liu RD, Xu BL, et al. Analysis of structures, functions, and epitopes of aminopeptidase from Trichinella spiralis. Trop Biomed. 2015;32:776-82.

40. Song $Y Y$, Zhang Y, Yang D, Ren HN, Sun GG, Jiang P, et al. The Immune protection induced by a serine protease inhibitor from the foodborne parasite Trichinella spiralis. Front Microbiol. 2018;9:1544.

41. Li LG, Wang ZQ, Liu RD, Yang X, Liu LN, Sun GG, et al. Trichinella spiralis: low vaccine potential of glutathione S-transferase against infections in mice. Acta Trop. 2015;146:25-32.

42. Xu J, Yang F, Yang DQ, Jiang P, Liu RD, Zhang X, et al. Molecular characterization of Trichinella spiralis galectin and its participation in larval invasion of host's intestinal epithelial cells. Vet Res. 2018;49:79.

43. Liu CY, Song YY, Ren HN, Sun GG, Liu RD, Jiang P, et al. Cloning and expression of a Trichinella spiralis putative glutathione S-transferase and its elicited protective immunity against challenge infections. Parasites Vectors. 2017;10:448.

44. Wang SW, Wang ZQ, Cui J. Protein change of intestinal epithelial cells induced in vitro by Trichinella spiralis infective larvae. Parasitol Res. 2011;108(3):593-9.

45. Wang ZQ, Wang L, Cui J. Proteomic analysis of Trichinella spiralis proteins in intestinal epithelial cells after culture with their larvae by shotgun LC-MS/MS approach. J Proteomics. 2012;75:2375-83.

46. Long SR, Wang ZQ, Liu RD, Liu LN, Li LG, Jiang P, et al. Molecular identification of Trichinella spiralis nudix hydrolase and its induced protective immunity against trichinellosis in BALB/c mice. Parasites Vectors. 2014;7:600

47. Cui J, Ren HJ, Liu RD, Wang L, Zhang ZF, Wang ZQ. Phage-displayed specific polypeptide antigens induce significant protective immunity against Trichinella spiralis infection in BALB/c mice. Vaccine. 2013;31:1171-7.

48. Wang B, Wang ZQ, Jin J, Ren HJ, Liu LN, Cui J. Cloning, expression and characterization of a Trichinella spiralis serine protease gene encoding a 35.5 kDa protein. Exp Parasitol. 2013;134:148-54.

49. Sun GG, Ren HN, Liu RD, Song YY, Qi X, Hu CX, et al. Molecular characterization of a putative serine protease from Trichinella spiralis and its elicited immune protection. Vet Res. 2018;49:59.

50. Long SR, Wang ZQ, Jiang P, Liu RD, Qi X, Liu P, et al. Characterization and functional analysis of Trichinella spiralis Nudix hydrolase. Exp Parasitol. 2015;159:264-73.

51. Liu CY, Ren HN, Song YY, Sun GG, Liu RD, Jiang P, et al. Characterization of a putative glutathione S-transferase of the parasitic nematode Trichinella spiralis. Exp Parasitol. 2018;187:59-66.

52. Ren HN, Guo KX, Zhang Y, Sun GG, Liu RD, Jiang P, et al. Molecular characterization of a $31 \mathrm{kDa}$ protein from Trichinella spiralis and its induced immune protection in BALB/c mice. Parasites Vectors. 2018;11:625.

53. Ren HJ, Cui J, Yang W, Liu RD, Wang ZQ. Identification of differentially expressed genes of Trichinella spiralis larvae after exposure to host intestine milieu. PLoS ONE. 2013;8:e67570.

54. Zhang YL, Wang ZQ, Li LG, Cui J. Molecular characterization of Trichinella spiralis aminopeptidase and its potential as a novel vaccine candidate antigen against trichinellosis in BALB/c mice. Parasites Vector. 2013;6:246.

55. Qi X, Yue X, Han Y, Jiang P, Yang F, Lei JJ, et al. Characterization of two Trichinella spiralis adult-specific DNase II and their capacity to induce protective immunity. Front Microbiol. 2018;9:2504.

56. Li JF, Guo KX, Qi X, Lei JJ, Han Y, Yan SW, et al. Protective immunity against Trichinella spiralis in mice elicited by oral vaccination with attenuated Salmonella-delivered TsSP1.2 DNA. Vet Res. 2018;49:87.
57. Liu LN, Wang ZQ, Zhang X, Jiang P, Qi X, Liu RD, et al. Characterization of Spirometra erinaceieuropaei plerocercoid cysteine protease and potential application for serodiagnosis of sparganosis. PloS Neglect Trop Dis. 2015;9:e0003807

58. Wang L, Tian XY, Sun GG, Liu RD, Liu LN, Zhang X, et al. The use of recombinant $31 \mathrm{kDa}$ antigens of Trichinella spiralis for serodiagnosis of experimental trichinellosis. Iran J Parasitol. 2015;10:230-7.

59. Wang ZQ, Lin XM, Zhang HW, Xu BL, Zhang X, Jiang P, et al. Serological survey for sparganum infection in people of central China. Helminthologia. 2014;51:158-61.

60. Sun GG, Lei JJ, Guo KX, Liu RD, Long SR, Zhang X, et al. Primary assessment of a T. spiralis putative serine protease for early serological detection of Trichinella infection. Trop Biomed. 2019;34:1-11.

61. Nishiyama T, Araki T, Mizuno N, Wada T, Ide T, Yamaguchi T. Detection of circulating antigens in human trichinellosis. Trans R Soc Trop Med Hyg. 1992;86:292-3

62. Li F, Wang ZQ, Cui J. Early Detection by Polymerase chain reaction of migratory Trichinella spiralis larvae in blood of experimentally infected mice. Foodborne Pathog Dis. 2010;7:887-92.

63. Liu XL, Ren HN, Shi YL, Hu CX, Song YY, Duan JY, et al. Early detection of Trichinella spiralis DNA in the feces of experimentally infected mice by using PCR. Acta Trop. 2017;166:351-5.

64. El-Faham MH, Wheatcroft-Francklow KJ, Price HP, Sayers JR, Doenhoff MJ. Schistosoma mansoni cercarial elastase (SmCE): differences in immunogenic properties of native and recombinant forms. Parasitology. 2017;144:1356-64.

65. Landsperger WJ, Stirewalt MA, Dresden MH. Purification and properties of a proteolytic enzyme from the cercariae of the human trematode parasite Schistosoma mansoni. Biochem J. 1982;201:137-44.

66. Lindquist RN, Senft AW, Petitt M, McKerrow J. Schistosoma mansoni: purification and characterization of the major acidic proteinase from adult worms. Exp Parasitol. 1986;61:398-404.

67. Salter JP, Choe Y, Albrecht H, Franklin C, Lim KC, Craik CS, et al. Cercarial elastase is encoded by a functionally conserved gene family across multiple species of schistosomes. J Biol Chem. 2002;277:24618-24.

68. Zhang T, Mo XJ, Xu B, Yang Z, Gobert GN, Yan S, et al. Enzyme activity of Schistosoma japonicum cercarial elastase $\mathrm{SjCE}-2 \mathrm{~b}$ ascertained by in vitro refolded recombinant protein. Acta Trop. 2018;187:15-22.

69. Krivokapich SJ, Pozio E, Gatti GM, Prous CL, Ribicich M, Marucci G, et al. Trichinella patagoniensis n. sp. (Nematoda), a new encapsulated species infecting carnivorous mammals in South America. Int J Parasitol. 2012:42:903-10.

70. Bien J, Cabaj W, Moskwa B. Proteomic analysis of potential immunoreactive proteins from muscle larvae and adult worms of Trichinella spiralis in experimentally infected pigs. Folia Parasitol. 2015;62:022.

71. Serrano FJ, Perez-Martin JE, Carron A, Navarrete I. Comparison of IgM, $\operatorname{lgG1}$ and IgG2 responses to Trichinella spiralis and Trichinella britovi in swine. Parasite. 2001;8(Suppl. 2):S133-5.

72. Morakote N, Sukhavat K, Khamboonruang C, Siriprasert V, Suphawitayanukul S, Thamasonthi W. Persistence of IgG, IgM, and IgE antibodies in human trichinosis. Trop Med Parasitol. 1992:43:167-9.

73. Tomasik J, Grzybowski J, Golinska Z, Prokopowicz D. Activity of specific IgG, IgM and IgE antibodies in human trichinellosis. Wiad Parazytol. 1992;38:127-33.

74. Gottstein B, Pozio E, Nockler K. Epidemiology, diagnosis, treatment, and control of trichinellosis. Clin Microbiol Rev. 2009;22:127-45.

\section{Publisher's Note}

Springer Nature remains neutral with regard to jurisdictional claims in published maps and institutional affiliations. 